\title{
REPRODUCTIVE CYCLES OF THE PEARL OYSTERS, PINCTADA FUCATA (GOULD) AND PINCTADA MARGARITIFERA (LINNAEUS) (BIVALVIA: PTERIIDAE) IN SOUTHWESTERN TAIWAN WATERS
}

Jiuan-Jiuan Hwang Department of Aquaculture, National Kaohsiung Marine University, No. 142, Hai-Chuan Rd., Nan-tzu, Kaohsiung, Taiwan, R.O.C., jannieh@mail.nkmu.edu.tw

Follow this and additional works at: https://jmstt.ntou.edu.tw/journal

Part of the Aquaculture and Fisheries Commons

\section{Recommended Citation}

Hwang, Jiuan-Jiuan (2007) "REPRODUCTIVE CYCLES OF THE PEARL OYSTERS, PINCTADA FUCATA (GOULD) AND PINCTADA MARGARITIFERA (LINNAEUS) (BIVALVIA: PTERIIDAE) IN SOUTHWESTERN TAIWAN WATERS," Journal of Marine Science and Technology. Vol. 15: Iss. 2, Article 1.

DOI: $10.51400 / 2709-6998.2034$

Available at: https://jmstt.ntou.edu.tw/journal/vol15/iss2/1

This Research Article is brought to you for free and open access by Journal of Marine Science and Technology. It has been accepted for inclusion in Journal of Marine Science and Technology by an authorized editor of Journal of Marine Science and Technology. 
REPRODUCTIVE CYCLES OF THE PEARL OYSTERS, PINCTADA FUCATA (GOULD) AND PINCTADA MARGARITIFERA (LINNAEUS) (BIVALVIA: PTERIIDAE) IN SOUTHWESTERN TAIWAN WATERS

\section{Acknowledgements}

This study was funded by the Fisheries Agency, Council of Agriculture, Executive Yuan (92AS-2.5.1- FAF1.11-3). Sincere gratitude to Professor Aoki and associate professor Yamakawa of the Tokyo University for their valuable comments on an earlier draft, and associate professor Yoshinaga for guidance in microphotographic technics. I would like to express my special thanks to Mr. C. Y. Liu for his help in measurement and histological sectioning for this study. I would further like to extend thanks to Dr. K. M. Liu National Taiwan Ocean University and Dr. T. Okutani for reviewing this manuscript. 


\title{
REPRODUCTIVE CYCLES OF THE PEARL OYSTERS, PINCTADA FUCATA (GOULD) AND PINCTADA MARGARITIFERA (LINNAEUS) (BIVALVIA: PTERIIDAE) IN SOUTHWESTERN TAIWAN WATERS
}

\author{
Jiuan-Jiuan Hwang*
}

Key words: Pinctadafucata, Pinctada margaritifera, gonadal development, spawning, sex ratio, Taiwan.

\begin{abstract}
The reproductive cycles of the pearl oysters Pinctada fucata (Gould) and Pinctada margaritifera (Linnaeus) were examined based on 339 and 284 specimens, collected in southwestern Taiwan. Except for the month of December 2002, Pinctada fucata were collected during the periods from March 2002 to September 2003. Pinctada margaritifera were collected over two periods: from March 2002 to November 2002 and from June 2003 to September 2003. Histological observations on gonadal development indicated that Pinctada fucata and Pinctada margaritifera were protandrous hermaphrodites, and both species exhibited different annual cyclical patterns, in which maturity peaked in May and October for Pinctada fucata, and in July and November for Pinctada margaritifera. Both species had two spawning periods a year. The onset of reproduction appears to be regulated by sea surface temperature. For both species, females outnumbered males during the spawning season.
\end{abstract}

\section{INTRODUCTION}

The pearl oysters, Pinctata fucata (Gould) and $P$. margaritifera (Linnaeus) inhabit temperate, subtropical and tropical coral reefs, and are widely distributed in the Indo-Pacific area, down to northern Australia throughout the equator extending up to the southernmost region of Japan. In Taiwan, $P$. fucata and $P$. margaritifera are distributed in Yenliau (Taipei County), Jukeng, Kenting (Pingtong County), Hugin (Penghu Archipelago) and Hualien [11, 13].

In 1893, half-pearls were created by Mikimoto in Japan; a decade later, round pearls were produced by

Paper Submitted 03/03/06, Accepted 06/01/06. Author for Correspondence: Jiuan-Jiuan Hwang. E-mail: jannieh@mail.nkmu.edu.tw.

*Department of Aquaculture, National Kaohsiung Marine University, No. 142, Hai-Chuan Rd., Nan-tzu, Kaohsiung, Taiwan, R.O.C.
Mise and Nishikawa [2, 12, 17]. Since then, a number of biological studies have been done on P. fucata (= martensii) in Japan. Pearl oysters draws research attention because their use in the commercial culturing of pearls can potentially provide economic benefits to the many countries where the resources are available. Japan has marketed and exported most of the world's round pearls, products of $P$. fucata species. Australia and the Indo-Pacific countries, including French Polynesia, Cook Islands, and Indonesia produce most the world's half-round (blister) pearls and a small part of the world's round pearls, both products of $P$. margaritifera [28].

For pearl production, gonadal maturation is important to pearl production, because it is essential to the artificial seed production and the preoperative procedures of the nucleus implantation. A large number of studies on the spawning period of P. fucata were published in the 1950s in Japan [19, 31, 38, 39, 45], and on the spawning period of $P$. margaritifera [27]. In Australia, Tranter [33-37] described three Pinctada species: P. albina, P. fucata and P. margaritifera. The gonadal development, maturation and spawning of these oysters have also been well documented [1, 3, 16, 20, 27, 30, 32, 40-43, 45]. In Taiwan, although a diversity of pearl oysters of the family Pteriidae have been found [11], little is known about the biological aspects of the wild stocks of these species. Therefore, this study investigates the reproduction cycles of wild stocks of two species, $P$. fucata and $P$. margaritifera in the waters of southwestern Taiwan. The results obtained in this study can provide useful information for pearl culture in the future.

\section{MATERIALS AND METHODS}

In total, 339 and 284 specimens of the pearl oysters Pinctada fucata and P. margaritifera were collected on 
a monthly basis from March 2002 to September 2003 (with the exception of December 2002), and from March 2002 to November 2002 and from June 2003 to September 2003 , respectively, by divers at 3 to $25 \mathrm{~m}$-depth in the coastal waters of southwestern Taiwan (Figure 1). The sea surface temperature (SST) of sampling sites was also recorded monthly. Specimens of Pinctada fucata and $P$. margaritifera ranged in size: 40.4-71.0 $\mathrm{mm}$ and 54.1-137.4 $\mathrm{mm}$, respectively (Table 1 ). The shell height (dorsoventral measurement) was measured with a vernier caliper to the nearest $0.1 \mathrm{~mm}$. In the histological observation of the gonadal development, the tissue of both species was sampled from the end of gut loop of the visceral mass. These samples were fixed in a $10 \%$ formaldehyde solution for 24 hours, and were then, washed and dehydrated in a series of ethanol from 70 to $100 \%$, embedded in paraffin, sectioned in $5 \mu \mathrm{m}$ thick, and stained with hematoxylin and eosin.

Gonadal development was determined by histological observation of specimen under a light microscope at the magnification of objective lenses $\times 20$ and $\times 40$ with an attached camera (video), following the procedures of Tranter [34, 35], Uemoto [39] and Wada et al. [42]. The schemes were identified by the size and density of various germ cells, which are formed from stem cells of gemetogenesis in the gonad.

\section{RESULTS}

\section{Gonadal development}

The gonadal development of both Pinctada fucata and $P$. margaritifera were no difference, can be categorized into six stages in males (Figure 2) as well as in females (Figure 3a-f), a few hermaphroditic individuals (Figure $3 \mathrm{~g}-\mathrm{h}$ ) were also identified as follows:

\section{Stage 1: Early developing stage}

The follicle walls were thick and small primary oogonia and few larger developing oocytes were attached to the follicle wall. In males, the follicle walls as well as stem cells lining the follicle walls were developing. At the same time, differentiation of spermatogonia, even a few spermatocytes could be observed. (Figures 2a and 3a)

\section{Stage 2: Developing stage}

The oocytes, more developed and appeared like pear-shape, are still attached to the follicle wall in females. Similarly, spermatocytes and spermatids filled the follicle lumen, while the male follicle walls become thinner. Compared to the previous stage, spermatogo-

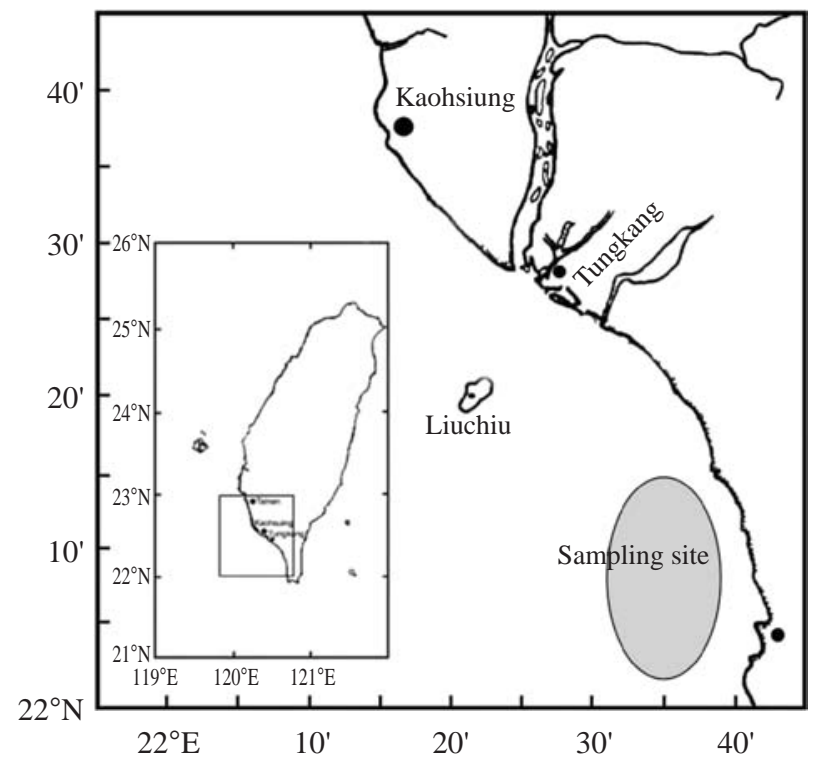

Fig. 1. Location of sampling area in the southwestern Taiwan.

nia attached to the follicle walls are fewer in number. (Figures $2 \mathrm{~b}$ and $3 \mathrm{~b}$ )

\section{Stage 3: Mature stage}

The follicle is full of mature, round and expanded oocytes, tightly connected to each other. A few oocytes are still attached to the wall by the stalk. In this stage, the follicle wall is swollen and indefinite. In males, there are larger quantities of mature spermatids. Free active tailed-spermatozoon are observed in the lumen central. (Figures $2 \mathrm{c}$ and $3 \mathrm{c}$ )

\section{Stage 4: Spawning stage}

The interstices between the oocytes are loosening with the release of ova. Free oocytes are spawning and the follicle wall is broken. Part of spermatozoon had been released and there are still active spermatozoa as well as spermatids remaining within the follicle, making the central lumen appear to be a little emptier. A few resorptive phagocytic cells have appeared. (Figures $2 \mathrm{~d}$ and $3 \mathrm{~d})$

Stage 5: Spent stage

Not all follicles are empty, because some free oocytes and some residual oocytes, which are small or not well-developed, remained. Some gametes remain unreleased in the lumen. Although phagocytes have cleared unreleased oocytes, spermatids and residual 
Table 1a. Specimens of Pinctada fucata used in histological study

\begin{tabular}{|c|c|c|c|c|c|c|c|}
\hline \multirow[b]{2}{*}{ Sample date } & \multirow[b]{2}{*}{ Number } & \multirow[b]{2}{*}{ Shell height $(\mathrm{mm})$} & \multirow[b]{2}{*}{ Shell width (mm) } & \multicolumn{4}{|c|}{ Sex } \\
\hline & & & & $\mathrm{M}$ & $\mathrm{F}$ & I & $\mathrm{H}$ \\
\hline Mar. 25, 2002 & 20 & $58.1 \sim 63.3$ & $25.0 \sim 24.5$ & 12 & 7 & 1 & \\
\hline Apr. 22 & 19 & $52.7 \sim 68.9$ & $21.4 \sim 26.6$ & 12 & 6 & & 1 \\
\hline May 24 & 16 & $42.7 \sim 69.8$ & $17.4 \sim 27.1$ & 8 & 7 & & 1 \\
\hline Jun. 17 & 16 & $52.8 \sim 60.5$ & $23.8 \sim 24.5$ & 9 & 7 & & \\
\hline Jul. 17 & 17 & $53.8 \sim 68.6$ & $22.5 \sim 26.6$ & 4 & 13 & & \\
\hline Aug. 15 & 19 & $55.7 \sim 67.5$ & $21.7 \sim 24.6$ & 3 & 2 & 14 & \\
\hline Sep. 14 & 21 & $56.5 \sim 67.0$ & $22.0 \sim 23.4$ & 9 & 6 & 6 & \\
\hline Oct. 12 & 20 & $60.0 \sim 68.5$ & $23.7 \sim 24.5$ & 6 & 14 & & \\
\hline Nov. 17 & 19 & $61.8 \sim 66.7$ & $24.2 \sim 24.4$ & 10 & 9 & & \\
\hline Jan. 16, 2003 & 18 & $40.4 \sim 68.3$ & $14.3 \sim 24.6$ & 9 & 8 & 1 & \\
\hline Feb. 16 & 20 & $64.4 \sim 69.1$ & $24.0 \sim 25.0$ & 9 & 4 & 7 & \\
\hline Mar. 15 & 19 & $63.6 \sim 70.6$ & $25.2 \sim 25.5$ & 9 & 7 & 3 & \\
\hline Apr. 18 & 19 & $69.3 \sim 71.0$ & $25.5 \sim 25.7$ & 6 & 11 & 1 & 1 \\
\hline May 18 & 23 & $69.5 \sim 70.4$ & $26.5 \sim 27.1$ & 11 & 12 & & \\
\hline Jun. 14 & 17 & $61.4 \sim 69.5$ & $22.9 \sim 25.8$ & 5 & 4 & 8 & \\
\hline Jul. 27 & 17 & $64.9 \sim 69.2$ & $22.7 \sim 23.4$ & 3 & 4 & 10 & \\
\hline Aug. 26 & 21 & $42.5 \sim 63.9$ & $15.6 \sim 22.6$ & 5 & 5 & 11 & \\
\hline Sep. 20 & 18 & $45.3 \sim 67.8$ & $15.7 \sim 24.1$ & 5 & 4 & 9 & \\
\hline
\end{tabular}

Table 1b. Specimens of Pinctada margaritifera used in histological study

\begin{tabular}{|c|c|c|c|c|c|c|c|}
\hline \multirow[b]{2}{*}{ Sample date } & \multirow[b]{2}{*}{ Number } & \multirow[b]{2}{*}{ Shell height $(\mathrm{mm})$} & \multirow[b]{2}{*}{ Shell width (mm) } & \multicolumn{4}{|c|}{ Sex } \\
\hline & & & & $\mathrm{M}$ & $\mathrm{F}$ & $\mathrm{I}$ & $\mathrm{H}$ \\
\hline Mar. 25, 2002 & 18 & $54.1 \sim 97.5$ & $13.5 \sim 24.9$ & 15 & 3 & & \\
\hline Apr. 22 & 17 & $87.5 \sim 96.8$ & $24.8 \sim 27.1$ & 14 & 3 & & \\
\hline May 24 & 19 & $96.8 \sim 105.2$ & $23.8 \sim 31.7$ & 14 & 5 & & \\
\hline Jun. 17 & 25 & $80.6 \sim 111.3$ & $20.3 \sim 27.8$ & 18 & 7 & & \\
\hline Jul. 17 & 17 & $78.3 \sim 106.2$ & $22.4 \sim 30.1$ & 6 & 8 & 1 & 2 \\
\hline Aug. 15 & 15 & $103.6 \sim 137.4$ & $30.5 \sim 34.7$ & 4 & 4 & 5 & 2 \\
\hline Sep. 14 & 21 & $81.1 \sim 122.8$ & $22.2 \sim 34.0$ & 4 & 13 & 4 & \\
\hline Oct. 12 & 25 & $88.5 \sim 92.3$ & $24.1 \sim 25.5$ & 12 & 12 & 1 & \\
\hline Nov. 17 & 16 & $89.6 \sim 128.0$ & $23.7 \sim 30.1$ & 9 & 7 & & \\
\hline Jun. 14, 2003 & 35 & $94.8 \sim 115.7$ & $26.1 \sim 27.5$ & 20 & 14 & 1 & \\
\hline Jul. 28 & 26 & $93.6 \sim 109.2$ & $28.1 \sim 29.2$ & 13 & 13 & & \\
\hline Aug. 27 & 30 & $96.1 \sim 107.6$ & $26.7 \sim 30.6$ & 15 & 15 & & \\
\hline Sep. 20 & 20 & $97.1 \sim 137.5$ & $28.0 \sim 37.2$ & 18 & 2 & & \\
\hline
\end{tabular}

Note: M: male, F: female, I: indeterminate, H: hermarphodites

mass, the sex can still be identified by the presence of the unresorped gametes. Follicle walls are shrunken and broken into debris. (Figures $2 \mathrm{e}$ and $3 \mathrm{e}$ )

Stage 6: Indeterminate stage

Sex can not be identified and gonad is actionless after spawning; only connective tissues are observed in this degenerative state. (Figures $2 \mathrm{f}$ and $3 \mathrm{f}$ )

\section{Hermaphrodities}

Both sex gametes are present in follicles, spermatids surrounding free oocytes (Figure $3 \mathrm{~g}$ ), ovary developed earlier than testis are also identified. (Figure 3g-h).

\section{Environment}

The SST of sampling area in 2002 ranged from 

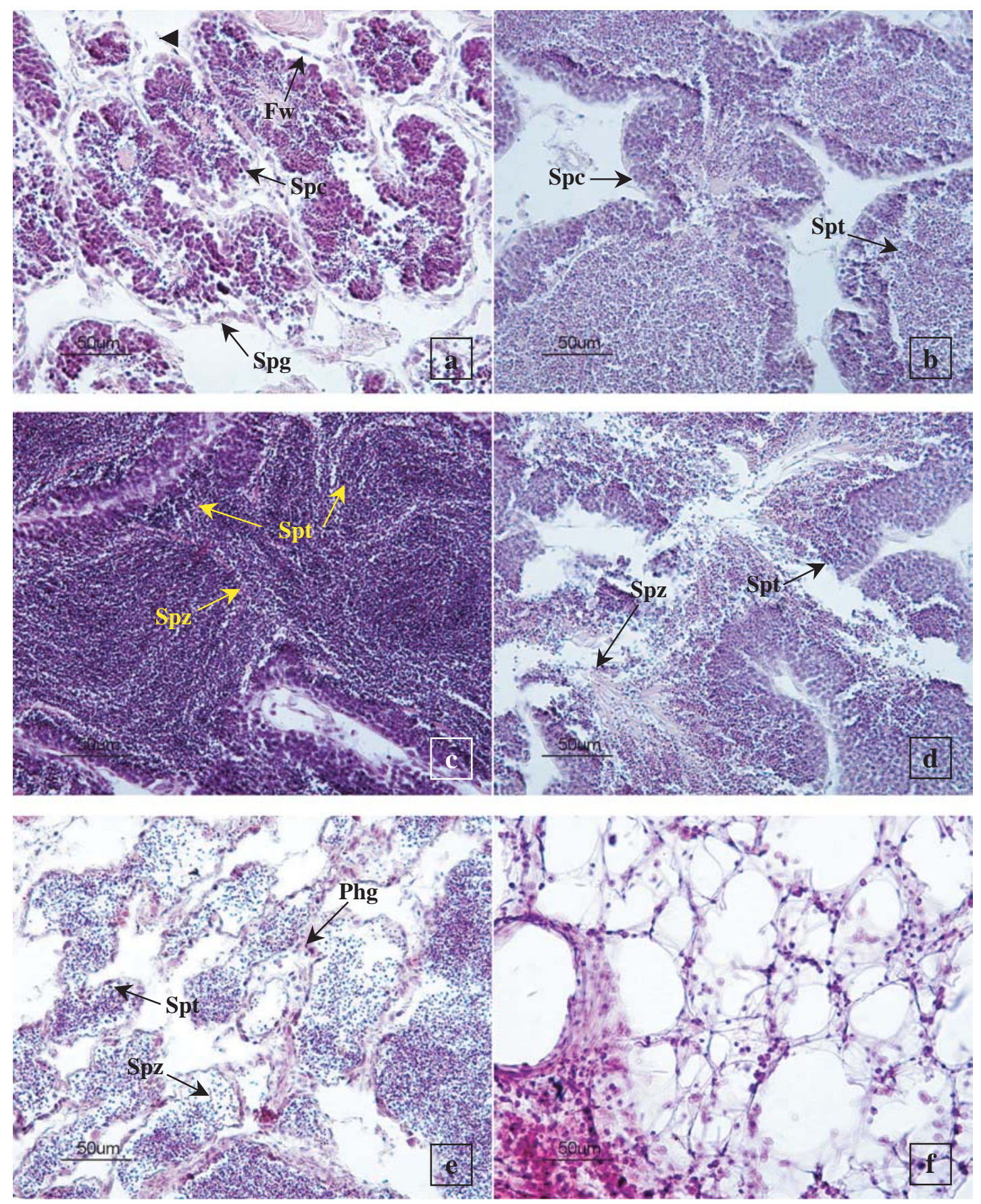

Fig. 2. Microphotographs of gonadal development stages of male $P$. margaritifera. (a) early developing; (b) developing; (c) mature; (d) spawning; (e) spent; (f) indeterminate.

Note: Fw: Follicle wall, Spg: Spermatogonium, Spc: Spermatocyte, Spt: Spermatid, Spz: Spermatozoon, Phg: Phagocyte.

$26^{\circ} \mathrm{C}$ in March to $30^{\circ} \mathrm{C}$ in September (Figure 4). The salinity ranged from $31.2 \mathrm{psu}$ at the lowest in August to $34.0 \mathrm{psu}$ at the highest in November.

\section{Development phases and spawning season}

Gonadal development cycles of Pinctada fucata and $P$. margaritifera were determined by development phases of histological observations (Figures 2 and 3). Population spawning was characterized by a high frequency of releasing at Stage 4 (Figure $5 \mathrm{a}$ and $5 \mathrm{c}$ ). In the year 2002, $P$. fucata had two spawning seasons, the major spawning occurred in May and the minor one in October. The gonadal development in the majority 

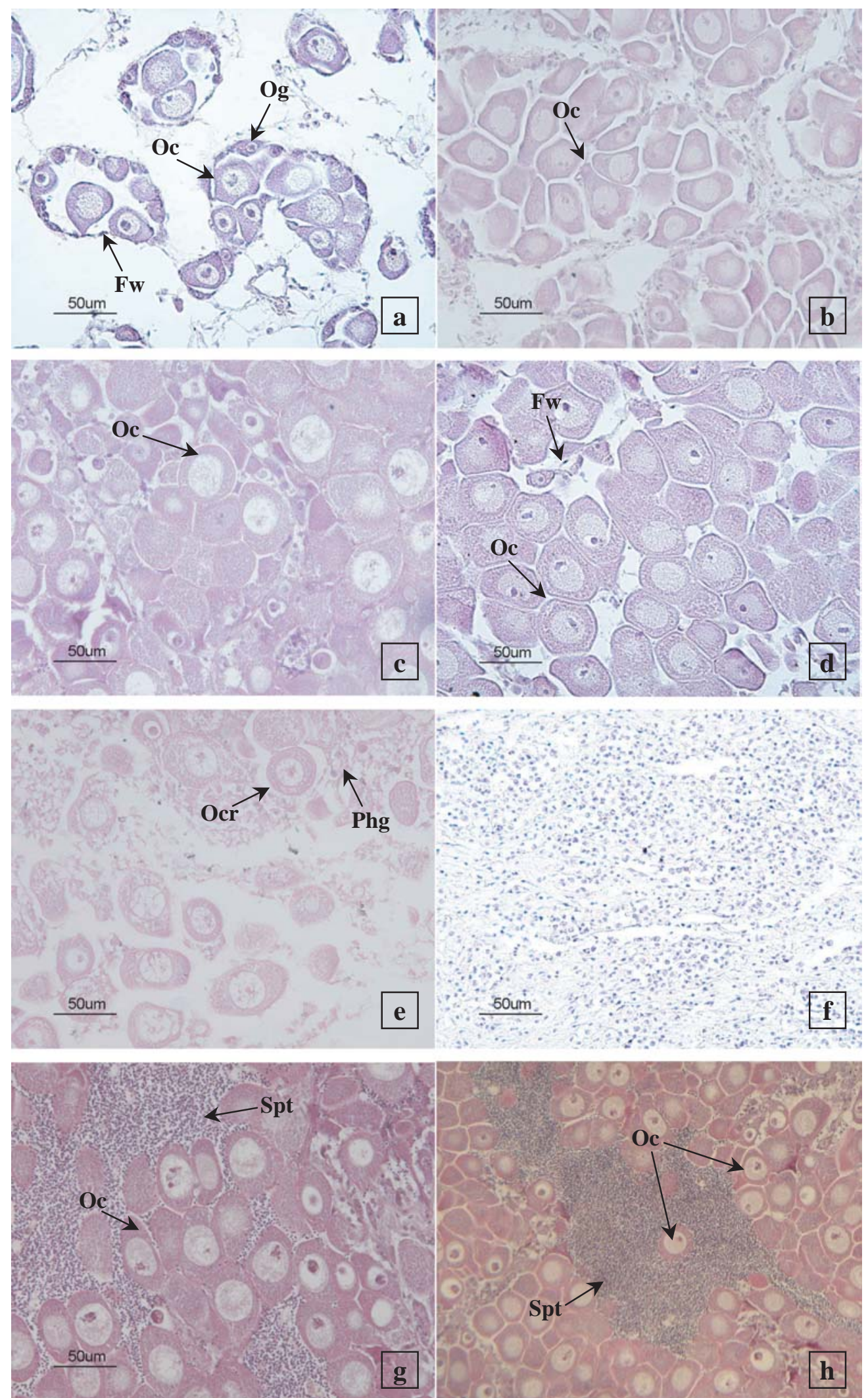

Fig. 3. Microphotographs of gonadal development stages of female $P$. margaritifera. (a) early developing; (b) developing; (c) mature; (d) spawning; (e) spent; (f) indeterminate; ( $g$ and $h$ ) hermaphroditic.

Note: Fw: Follicle wall, Og: Oogonium, Oc: Oocyte, Ocr: residual Oocyte, Phg: Phagocyte, Spt: Spermatid. 
onset in January (Figure 5a) and continued to April. In May, the gonads of most specimens were in Stages 3 and 4. After the main spawning period, the gonads exhibited a high proportion of Stage 5 and Stage 6 from June to August. In September, gonads began to develop again rapidly. About one month later, the second peak of maturity occurred in October and in November.

Gonadal development cycle in Pinctada margaritifera was similar to that in $P$. fucata, with two spawning seasons in a year (Figure 5c), though at different times. Individuals in stages $2-3$ appeared in high frequency from March to June. The main spawning occurred in July, followed by August. After that time, gonads at Stages 1-2 were found in September. Oysters matured rapidly over a short time period during October, and the second spawning peak began in November.

\section{Sex ratio}

The monthly variation of sex ratio of Pinctada fucata and P. margaritifera are shown in Figure 5b and 5 d respectively. In all $P$. fucata sampled, 135 (39.8\%) specimens were males, 130 (38.3\%) were females, 71 (20.9\%) were indeterminate and $3(0.9 \%)$ of $P$. fucata were hermaphroditic. Sex ratio (females: males) was 1 : 1.04, which was not significantly different from $1: 1\left(\chi^{2}\right.$ test, $\mathrm{p}>0.05)$. In P. margaritifera, $162(57.0 \%)$ specimens were males, $106(37.2 \%)$ were females, $12(4.1 \%)$ were indeterminate, and $4(1.7 \%)$ were hermaphroditic. The sex ratio was $1: 1.53\left(\chi^{2}\right.$ test, $\left.\mathrm{p}<0.05\right)$. While males outnumbered the females in both species in the early spring of 2002, females tended to outnumber males during the spawning season, in May and in July. After spawning, the sex of oysters, with few exceptions, at stage 5 and 6 were indeterminable. In $P$. margaritifera, males outnumbered the females (around $70 \%$ ) from March to June and in November of the year 2002, though, numbers of females increased from July to October. Hermaphroditic specimens of both $P$. fucata and $P$. margaritifera were observed around the months of spawning season.

\section{DISCUSSION}

Reproductive patterns and processes are quite varied in marine invertebrates [7]. Some species of potential culture or commercially shellfish are known to have annual reproductive cycles, but some bivalves have two spawning peaks per year, such as green mussel Perna viridis [21], pipi Paphies australis [9, 10], and hard clams Mercenaria spp. [8] and others. Similar characteristics have also been seen in pearl oysters, including Pinctada albina [33], P. maxima [18, 24, 29], $P$. mazatlanica and Pteria sterna [26].

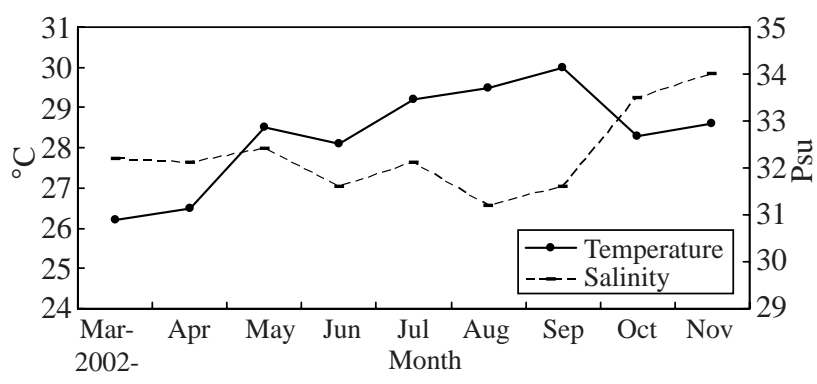

Fig. 4. Seasonal changes in surface water temperature and salinity of the sampling area.
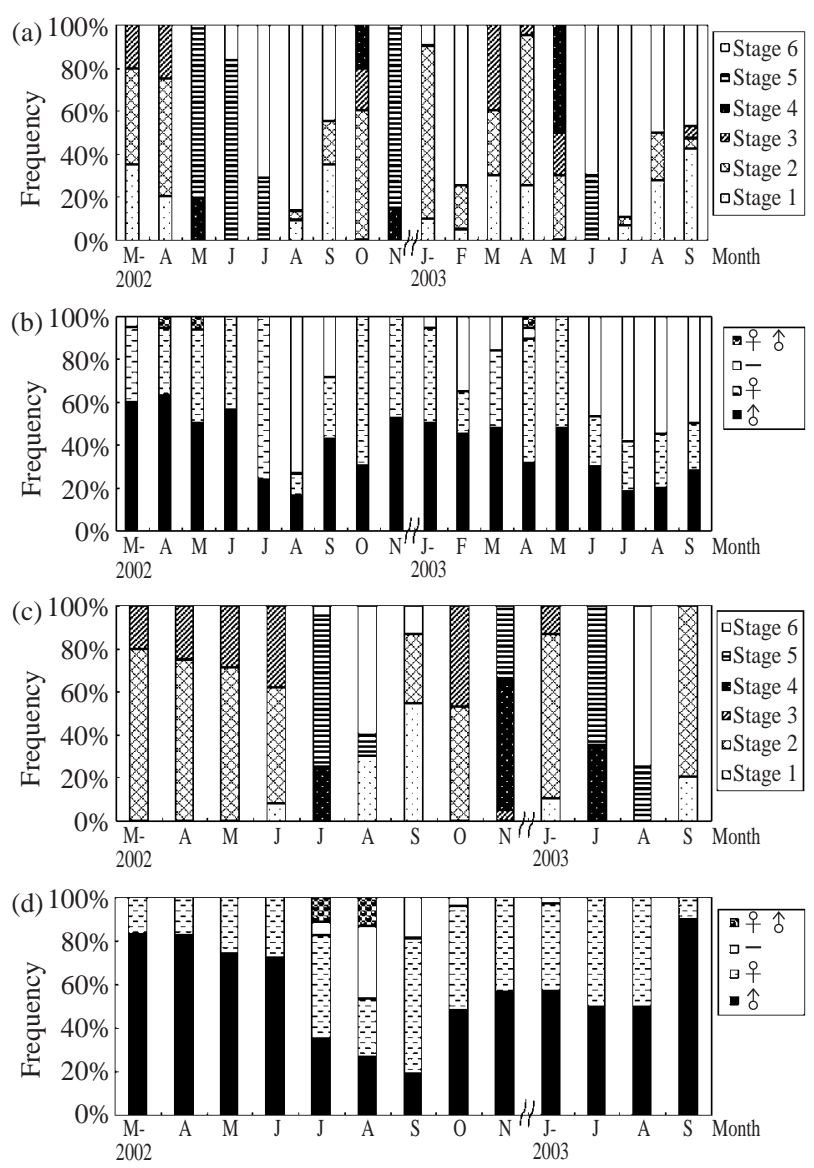

Fig. 5. The monthly frequency distribution of gonadal development stages (male and female combined) and the sex ratio of Pinctada species. (a) Gonadal stages of $P$. fucata; (b) Sex of $P$. fucata; (c) Gonadal stages of $P$. margaritifera; (d) Sex of $P$. margaritifera. (a and c, Stage 1: early development stage; Stage 2: development stage; Stage 3: mature stage; Stage 4: spawning stage; Stage 5: spent stage; Stage 6: indeterminate stage)

The spawning peak of $P$. fucata varies by locality. Pinctada fucata spawns in June/July in Korea [3], in July in Iran [1], and in August/ September in Japan [31, 45]. In addition, Pinctada fucata in Zamami Island, Okinawa, matures year round with a major peak in 
winter and a minor one in summer [42]. This observation is different from the findings in the present study, even though the Okinawa is geographically close to Taiwan. The difference in spawning season of $P$. fucata between Zamami Island and Taiwan was probably a result of environmental conditions, including current, temperature, salinity and availability of food in these two areas.

In Pinctada margaritifera, the major spawning occurred in July and the minor one in November in Taiwan, which was similar to that in Kagoshima, Japan [27], but was different from that in the Red Sea, where spawning occurs in June [4]. Year round multispawning has been noted in French Polynesia [20], such behavior possibly being attributed to complicated factors, including latitudinal position [22, 24, 42] and temperature $[5,6,14]$. Mature individuals are induced and spawn when animals receive a thermal shock or are exposed in diluted sperm solution $[9,10]$.

Spawning season with the thermal-saline factors at the sampling site of the present observation (Figure 4) revealed that the first spawning peak of $P$. fucata in present study was associated with a rising of seawater temperature from $26.5^{\circ} \mathrm{C}$ in April to $28.5^{\circ} \mathrm{C}$ in May, and the second spawning occurred when water temperature decreased from $30^{\circ} \mathrm{C}$ in September to $28.3^{\circ} \mathrm{C}$ in October, which are significantly different $(\mathrm{p}<0.05$, ANOVA, the mean temperature and multiple comparison). Similarly, the first spawning of $P$. margaritifera occurred with the increase of temperature from $28.1^{\circ} \mathrm{C}$ in June to $29.2^{\circ} \mathrm{C}$ in July ( $\mathrm{p}<0.05)$. The second peak was also provoked by a rising of temperature from $28.3^{\circ} \mathrm{C}$ in October to $28.6^{\circ} \mathrm{C}$ in November $(\mathrm{p}<0.05)$. This observation showed that the high temperatures in August and September seemed to have influence the release of gametes and the decrease in temperature made it possible for the gonads to quickly ripen in a short period, resulting in the second spawning.

In the first spawning seasons of both species, there was no obvious change in salinity $(p>0.05$, ANOVA, the mean temperature and multiple comparison). Salinity, however, increased drastically from $31.6 \mathrm{psu}$ in September to as high as 33.5 psu in October, and 34 psu in November corresponding to the second spawning periods for $P$. fucata and $P$. margaritifera ( $\mathrm{p}<0.05$ ). Therefore, author suspect that the spawning seasons of $P$. fucata and $P$. margaritifera are associated with changes in water temperature, which are probably accompanied by fluctuations in salinity. In Japan, thermal stimulation has been used for a long time to promote gonad development and induce spawning in the seed production and pearl cultural technique used for $P$. fucata and $P$. margaritifera [30, 40, 43].

Hermaphroditic pearl oysters have been reported in the past [24, 35-37, 39]. Wada [44] and Tranter [35-37] both suggested that pearl oysters, such as $P$. fucata, $P$. margaritifera, $P$. maxima and $P$. albina were protandric hermaphrodites. Sex changes from male to female, and female to male were also described. The present study found the protandric trend condition for $P$. fucata and P. margaritifera in Taiwan. A few hermaphrodite individuals were also detected at the time close to spawning seasons. The predominance of males was usual in early development stages in both $P$. fucata and $P$. margaritifera, but females outnumbered males during the spawning season. Pinctada fucata and $P$. margaritifera had a protandric tendency. While this study only found a few hermaphrodites they are often found in species of genera Pinctada. The protogynic tendency of $P$. fucata was also reported by Tateishi and Adachi [31] Japan. Uemoto [39] found that the sex ratio in $P$. martensii (= fucata) was 1 우: 1.29 송 $(43.7 \%$ 우: 56 . $3 \% \hat{\delta}$ ) in the three and four-year-old adult individuals. In other bivalves, the females become predominant with increase of size and age, as documented in Arctica islandica [23] and in Crassostrea virginica [15]. However, there was no significant difference in number between males and females for oysters above $40 \mathrm{~mm}$ in shell height in this study.

In addition, sexuality indeterminate individuals appeared in the period after spawning, especially in summer. This phenomenon was possibly due to the gonad entering a resting period after spawning, the gametes cell starting to degenerate.

In conclusion, although temperature has been the important environmental factor in bivalve reproductive physiology [25], salinity is also an element that needs to be taken into consideration. This study confirmed that reproductive cycle of Pinctada fucata and P. margaritifer in Taiwan waters has two spawning peaks but with different cycles in different months a year. Temperature may play an important role in oyster maturity and spawning.

\section{ACKNOWLEDGEMENTS}

This study was funded by the Fisheries Agency, Council of Agriculture, Executive Yuan (92AS-2.5.1FA-F1.11-3). Sincere gratitude to Professor Aoki and associate professor Yamakawa of the Tokyo University for their valuable comments on an earlier draft, and associate professor Yoshinaga for guidance in microphotographic technics. I would like to express my special thanks to Mr. C. Y. Liu for his help in measurement and histological sectioning for this study. I would further like to extend thanks to Dr. K. M. Liu National Taiwan Ocean University and Dr. T. Okutani for reviewing this manuscript. 


\section{REFERENCES}

1. Behzadi, S., Parivar, K., and Roustaian, P., "Gonadal Cycle of Pearl Oyster, Pinctada fucata (Gould) in Northeast Persian Gulf, Iran," Journal of Shellfish Research, Vol. 16, No. 1, pp. 129-135 (1997).

2. Carino, M. and Monteforte, M., "History of Pearling in La Paz Bay, South Baja California," Gems \& Gemology, Summer, pp. 88-105 (1995).

3. Choi, Y.H. and Chang, Y.J., "Gametogenic Cycle of the Transplanted-Cultured Pearl Oyster, Pinctada fucata martensii (Bivalvia: Pteriidae) in Korea," Aquaculture, Vol. 220, pp. 781-790 (2003).

4. Crossland, L., "The Cultivation of the Mother-of Pearl Oyster in the Red Sea," Journal of Marine and Freshwater Research, Vol. 8, pp. 111-130 (1957).

5. Eversole, A.G., "Gametogenesis and Spawning in North American Clam Populations: Implications for Culture," In J.J. Manzi and M. Castagna (eds.), Clam Mariculture in North America, Elsevier, Amsterdam, pp. 75-109 (1989).

6. Galtsoff, P.S., "The American Oyster, Crassostrea virginica Gmelin," United States Fish Wildlife Service, Fisheries Bulletin, Vol. 64, pp. 1-480 (1964).

7. Giese, A.C. and Pearse, J.S., Reproduction of Marine Invertebrates, Vol. V, Academic Press, New York (1979).

8. Hesselman, D.M., Barber, B.J., and Blake, N.J., "The Reproductive Cycle of Adult Hard Clams, Mercenaria spp. in the Indian River Lagoon, Florida," Journal of Shellfish Research, Vol. 8, pp. 43-49 (1989).

9. Hooker, S.H. and Creese, R.G., "The Reproductive Biology of Pipi, Paphies australis (Gmelin, 1790) (Bivalvia: Mesodesmatidae). I. Temporal Patterns of the Reproductive Cycle," Journal of Shellfish Research, Vol. 14, No. 1, pp. 7-15 (1995a).

10. Hooker, S.H. and Creese, R.G., "The Reproductive Biology of Pipi, Paphies australis (Gmelin, 1790) (Bivalvia: Mesodesmatidae) II. Spatial Patterns of the Reproductive Cycle," Journal of Shellfish Research, Vol. 14, No. 1, pp. 17-24 (1995b).

11. Hwang, J.J. and Okutani, T., "Taxonomy and Distribution of the Genera Pteria and Pinctada (Bivalvia: Pteriidae) in Taiwan," Journal of the Fisheries Society of Taiwan, Vol. 30, No. 3, pp. 185-202 (2003).

12. Isowa, K., "Historical View of the Pearl Formation Studies," Bulletin of National Pearl Research Laboratory, Vol. 1, pp. 47-56 (1956). (In Japanese)

13. Jung, B.S., "Pteriid of Eastern Taiwan," The Pei-Yo, No. 28, pp. 4-7 (2002). (In Chinese)

14. Keck, R.T., Maurer, D., and Lind, H., "A Comparative Study of the Hard Clam Gonad Developmental Cycle," The Biological Bulletin, Vol. 148, pp. 243-258 (1975).

15. Kennedy, V.S., "Sex Ratios in Oysters, Rmphasizing Crassostrea virginica from Chesapeake Bay,
Maryland," The Veliger, Vol. 25, No. 4, pp. 329-338 (1983).

16. Kuwatani, Y., "Studies on the Breeding of the Japanese Pearl Oyster, Pinctada martensii (Dünker), I. Change in the Maturation of the Eggs Obtained from the Excised Gonads During the Spawning Season," Bulletin of National Pearl Research Laboratory, Vol. 10, pp. 1228-1243 (1965). (In Japanese)

17. Matsui, Y., "On the Origin of Pearl-Culture and the History of It in Japan," Bulletin Faculty of Agriculture, Vol. 8, pp. 1-6 (1975).

18. Minaur, J., "Experiments on the Artificial Rearing of the Larvae of Pinctada maxima (Jameson) (Lamellibranchia)," Australian Journal of Marine and Freshwater Research, Vol. 20, pp. 175-187 (1969).

19. Ojima, Y. and Maeki, K., "Some Observations on Spermatogenesis and Oogenesis in the Pearl-Oyster (Pteria martensii Dünker)," Japanese Journal of Genetics, Vol. 30, pp. 151-157 (1955). (In Japanese)

20. Pouvreau, S., Gangnery, A., Tiapari, J., Lagarde, F., Garnier, M., and Bpdpu, A., "Gametogenic Cycle and Reproductive Effort of the Tropical Blacklip Pearl Oyster, Pinctada margaritifera (Bivallvia: Pteriidae), Cultivated in Takapoto Atoll (French Polynesia)," Aquatic Living Resources, Vol. 13, No. 1, pp. 37-48 (2000).

21. Rajagopal, S., Venugopalan, V.P., Nair, K.V.K., van der Velde, G., Jenner, H.A., and den Hartog, C., "Reproduction, Growth Rate and Culture Potential of the Green Mussel, Perna viridis (L.) in Edaijur Backwater, East Coast of India," Aquaculture, Vol. 162, pp. 187-202 (1998).

22. Ropes, J.W. and Stickney, A.P., "Reproductive Cycle of Mya arenaria in New England," The Biological Bulletin, Vol. 128, pp. 315-327 (1965).

23. Ropes, J.W., Murawski, S.A., and Serchuk, F.M., "Size, Age, Sexual Maturity, and Sex Ratio in Ocean Quahogs, Arctica islandica Linne, off Long Island, New York," Fishery Bulletin, Vol. 82, pp. 253-267 (1984).

24. Rose, R.A., Dybdahl, R.E., and Harders, S., "Reproductive Cycle of the Western Australian Silver-Lip Pearl Oyster Pinctada maxima (Jameson) (Mollusca: Pteriidae), " Journal of Shellfish Research, Vol. 9, pp. 261-272 (1990).

25. Sastry, A.N., " Pelecypoda (Excluding Ostreidae), "In A.C. Giese \& J.S. Pearse (eds.) Reproduction of Marine Invertebrates, Molluscs: Pelecypods and Lesser Classes, Vol. 5, pp. 113-332, Academic Press, New York (1979).

26. Saucedo, P. and Monteforte, M., "Breeding Cycle of Pearl Oysters Pinctada mazatlanica and Pteria sterna (Bivalvia:Pteriidae) at Baha de La Paz, Baja California Sur, Mexico," Journal of Shellfish Research, Vol. 16, pp. 103-110 (1997).

27. Setoguchi, I., "Histological Observation of the Seasonal Gonadal Samples of Pinctada margaritifera," Annual 
Report of Kagoshima Fisheries Experimental Station for 1959, pp. 143-152 (1960). (In Japanese)

28. Sims, N., "Pearl Oyster," Information Bulletin, No. 2, pp. 1-14 (1990).

29. Tanaka, Y. and Kumeta, M., "Successful Artificial Breeding of the Silver-Lip Pearl Oyster, Pinctada maxima (Jameson)," Bulletin of the National Research Institute of Aquaculture, Vol. 2, pp. 21-28 (1981). (In Japanese)

30. Tanaka, Y., Inoha, S., and Kakasu, K., "Studies on Seed Production of Black-Lip Pearl-Oyster, Pinctada margaritifera, in Okinawa-I," Bulletin of Tokai Regional Fisheries Research Laboratory, Vol. 63, pp. 75-78 (1970).

31. Tateishi, S. and Adachi, I., "Histological Observation of the Gonad of the Pearl-Oyster Pinctada martensii (Dünker)," Bulletin of the Faculty of Fisheries, Nagasaki University, Vol. 5, pp. 75-79 (1957). (In Japanese)

32. Thielley, M., Weppe, M., and Herbaut, C., "Ultrastructural Study of Gametogenesis in the French Polynesian Black Pearl Oyster, Pinctada margaritifera (Mollusca, Bivalvia). I. Spermatogenesis," Journal of Shellfish Research, Vol. 12, pp. 41-47 (1993).

33. Tranter, D.J., "Reproduction in Australian Pearl Oyster (Lamellibranchia). I. Pinctada albina (Lamarck): Primary Gonad Development," Australian Journal of Marine and Freshwater Research, Vol. 9, pp. 135-143 (1958a).

34. Tranter, D.J., "Reproduction in Australian Pearl Oyster (Lamellibranchia). II. Pinctada albina (Lamarck): Gametogenesis," Australian Journal of Marine and Freshwater Research, Vol. 9, pp. 144-158 (1958b).

35. Tranter, D.J., "Reproduction in Australian Pearl Oyster (Lamellibranchia). III. Pinctada albina (Lamarck): Bredding Season and Sexuality," Australian Journal of Marine and Freshwater Research, Vol. 9, pp. 191-216 (1958c).

36. Tranter, D.J., "Reproduction in Australian Pearl Oyster (Lamellibranchia). IV. Pinctada margaritifera (Linnaeus)," Australian Journal of Marine and Freshwater Research, Vol. 9, pp. 509-525 (1958d).

37. Tranter D.J., "Reproduction in Australian Pearl Oyster
(Lamellibranchia). V. Pinctada fucata (Gould)," Australian Journal of Marine and Freshwater Research, Vol. 10, pp. 45-66 (1959).

38. Uemoto, H., "Studies on the Gonad of the Pearl Oyster Pinctada martensii (Dünker), I. Histological Observations of the Gonad with Special Regard to the Change During the Course of the Artificial Spawning," Bulletin of the National Pearl Research Laboratory, Vol. 3, pp. 183-193 (1957). (In Japanese)

39. Uemoto, H., "Studies on the Gonad of the Pearl Oyster Pinctada martensii (Dünker), II. Histological Observation with Regard to Both the Seasonal Variation and the Change During the Course of the Artificial Spawning," Bulletin of the National Pearl Research Laboratory, Vol. 4, pp. 287-307 (1958). (In Japanese)

40. Wada, K.T., "Temperature Requirement for Maturation of Gonads in Japanese Pearl Oyster," Bulletin of the National Pearl Research Laboratory, Vol. 20, pp. 22442253 (1976). (In Japanese)

41. Wada, K.T., "Breeding Study of the Pearl Oyster, Pinctada fucata," Bulletin of National Research Institute of Aquaculture, No. 6, pp. $79-157$ (1984). (In Japanese)

42. Wada, K.T., Komaru, A., Ichimura, Y., and Kurosaki, H., "Spawning Peak Occurs During Winter in the Japanese Subtropical Population of the Pearl Oyster, Pinctada fucata fucata (Gould, 1850)," Aquaculture, Vol. 133, pp. 207-214 (1995).

43. Wada, S., "Akoyagai no Horanseishigeki Toshiteno Ondo," Suisangakkaiho, Vol. 7, No. 2, pp. 131-133 (1936). (In Japanese)

44. Wada, S., "Biology and Fisheries of the Silver-Lip Pearl Oyster," Suisanzoshoku, Vol. 1, pp. 1-50 (1953). (In Japanese)

45. Yagihara, H., Tateishi, S., and Fujioka, S., "Histological Observation of the Gonad of the Pearl-Oyster, Pinctada martensii (Dünker)-On the Monthly Variation of Gonad Maturity at Those Coasts in Different Environmental Conditions," Bulletin of the Faculty of Fisheries, Nagasaki University, Vol. 8, pp. 259-269 (1959). (In Japanese) 